DOI: $10.17951 / \operatorname{lrp} .2016 .35 .1 .179$

\author{
WIESŁAWA WALC
}

Uniwersytet Rzeszowski

\title{
ROLA PEDAGOGA SZKOLNEGO W OPINIACH STUDENTÓW PEDAGOGIKI
}

\begin{abstract}
Abstrakt: Pedagog szkolny jest specjalistą najczęściej zatrudnianym w polskich szkołach. Zawód ten istnieje od roku szkolnego 1973/74 i przez wiele lat starano się sprecyzować katalog zadań pełnionych przez jego przedstawicieli. W tekście dokonano prezentacji procesu kształtowania się specyfiki roli zawodowej pedagogów szkolnych. Przeanalizowano również wyniki badań dotyczących tej problematyki, przeprowadzonych wśród studentek pedagogiki Uniwersytetu Rzeszowskiego. Zaprezentowano opinie respondentek na temat zadań pedagoga szkolnego, trudności i barier w ich realizacji, modelu tego specjalisty (jego pożądanych cech, wiedzy i umiejętności), a także chęci i gotowości pracy w tym zawodzie.
\end{abstract}

Słowa kluczowe: pedagog szkolny, szkoła, pomoc psychologiczno-pedagogiczna

\section{WPROWADZENIE}

Pedagog szkolny jest specjalistą najczęściej - chociaż niestety jeszcze nie powszechnie - zatrudnianym w polskich szkołach. Wprawdzie przepisy ministerialne stworzyły podstawy do obecności w szkołach (oraz przedszkolach i placówkach oświatowych) także psychologów, logopedów, doradców zawodowych i terapeutów pedagogicznych, jednak to pedagodzy pracują w nich najczęściej. Tendencję do zatrudniania w szkołach specjalistów należy ocenić jak najbardziej pozytywnie - współcześnie pojawia się w nich ogrom różnego rodzaju problemów, trudności, z którymi muszą sobie radzić uczniowie, ich rodzice oraz nauczyciele, do ich rozwiązywania konieczna jest profesjonalna pomoc. Obecność pedagoga należałoby więc traktować jako niezbędne minimum pozwalające właściwie organizować i prowadzić 
pracę szkoły - zwłaszcza pozadydaktyczną. Niezwykle ważne jest również jasne i konkretne sformułowanie zadań tego szkolnego specjalisty, a także określenie jego modelu (pożądanych cech osobowościowych, wiedzy i umiejętności). Tych zagadnień dotyczyły przeprowadzone przez autorkę wśród studentów pedagogiki badania ankietowe, których wyniki zostaną zaprezentowane w dalszej części tekstu. Warto jednak przedtem przypomnieć, jak rolę pedagoga ujmowały i ujmują przepisy prawne oraz znawcy tematu.

\section{ZADANIA PEDAGOGA SZKOLNEGO DAWNIEJ I WSPÓŁCZEŚNIE}

Powołanie w roku szkolnym 1973/74 stanowiska pedagoga szkolnego w polskich szkołach było swoistym eksperymentem, odpowiedzią na pojawiające się w nich trudności wychowawcze, niepowodzenia dydaktyczne, objawy nieprzystosowania (Badora, Czeredrecka, Marzec 2001, s. 137). Lakoniczny zapis w instrukcji, stanowiącej załącznik do zarządzenia Ministra Oświaty i Wychowania, określał wówczas, że zadaniem pedagoga szkolnego ma być organizacja i koordynacja działalności szkoły w zakresie opieki nad dzieckiem oraz pomocy wychowawczej, a także podnoszenie poziomu kultury pedagogicznej rodziców. Podstawą do bardziej szczegółowego sformułowania zakresu jego działań i obowiązków miały się stać praktyka szkolna i doświadczenia pierwszych zatrudnionych pedagogów (Charakterystyka zawodu).

W roku 1975 pojawiły się konkretne przepisy prawne w tym zakresie. Ministerstwo Oświaty i Wychowania określiło pięć obszarów zadań pedagogów szkolnych: zadania ogólnowychowawcze, profilaktykę wychowawczą, pracę korekcyjno-wyrównawczą, indywidualną opiekę pedagogiczno-psychologiczną, organizację pomocy materialnej (Załącznik do Zarządzenia Ministra Oświaty 1975). W roku 1976 Ministerstwo Oświaty i Wychowania przedstawiło Zarys modelu nauczyciela-pedagoga szkolnego. Uznano go za inicjatora i współorganizatora pracy wychowawczo-opiekuńczej na terenie szkoły, a także współkoordynatora i reprezentanta szkoły oraz spraw uczniów w kontaktach z pozaszkolnymi instytucjami (Charakterystyka zawodu).

Niewątpliwym wkładem w określanie specyfiki zawodu pedagoga szkolnego była opublikowana w 1980 roku książka Ireny Jundziłł Rola zawodowa pedagoga szkolnego, w całości poświęcona zadaniom tego nowego w ówczesnej szkolnej rzeczywistości pracownika pedagogicznego (Jundziłł 1980). Pożądane sfery działalności pedagoga autorka ujęła wyjątkowo szeroko, zaliczając do nich nie tylko domenę jego aktywności - pracę wychowawczą, lecz także organizację przez niego procesu dydaktycznego w szkole, kształtowanie kultury pedagogicznej społeczeństwa, 
organizację i koordynację wychowania w miejscu zamieszkania oraz działalność naukową (Jundziłł 1980, s. 58-227).

Trzynaście lat po opublikowaniu swojej monografii poświęconej pedagogowi szkolnemu I. Jundziłł nieco zmodyfikowała koncepcję zadań przypisywanych temu specjaliście. Samego pedagoga szkolnego określiła jako osobę zatrudnioną w szkole w celu uzupełniania, pogłębiania i rozszerzania działalności dydaktyczno-wychowawczej i opiekuńczej prowadzonej przez nauczycieli (Jundziłł 1993, s. 533). Jego zadania natomiast ujęła w pięć głównych, złożonych grup, jak: współudział w organizowaniu procesów dydaktycznych; praca opiekuńczo-wychowawcza; współdziałanie z dyrekcją szkoły w zakresie kształtowania kultury pedagogicznej rodziców; organizowanie i koordynowanie pracy opiekuńczo-wychowawczej w środowisku; działalność naukowa (Jundziłł 1993, s. 534).

Ukazujące się w kolejnych latach ministerialne dokumenty wyraźnie odzwierciedlają tendencję do precyzowania i ograniczania zadań pedagoga szkolnego. Warto podkreślić, iż od dawna jego rolę określają przepisy w sprawie pomocy psychologiczno-pedagogicznej dla dzieci i młodzieży - nie ma odrębnych dokumentów dotyczących pedagoga szkolnego (Zarządzenie Nr 15 Ministra Edukacji Narodowej 1993. \$8.4; Rozporządzenie Ministra Edukacji Narodowej 2001. \$14.3; Rozporządzenie Ministra Edukacji Narodowej i Sportu 2003. \$15.3).

Od roku 2003 pedagodzy szkolni nie są jedynymi specjalistami, których można (przynajmniej teoretycznie) zatrudniać w szkołach. Mogą w nich pracować również psycholodzy, logopedzi i doradcy zawodowi, a od 2013 r. - terapeuci pedagogiczni (Rozporządzenie Ministra Edukacji Narodowej 2003. \$15.2; Rozporządzenie Ministra Edukacji Narodowej 2013. \$26). Wszyscy ci specjaliści uzupełniają pracę pedagoga, niekiedy przejmują część jego specjalistycznych zadań.

Do standardowych zajęć pedagoga szkolnego, faktycznie realizowanych w rzeczywistości polskich szkół, Mirosław Sałasiński i Beata Badziukiewicz - autorzy jednej z bardzo nielicznych publikacji poświęconych temu zawodowi - zaliczyli następujące:

1) współpracę z dyrekcją szkoły w zakresie planowania i realizowania programu wychowawczego szkoły oraz innych planów i programów związanych z wychowaniem, profilaktyką społeczną, rozwojem osobowym uczniów, poprawianiem jakości pracy szkoły;

2) współpracę z wychowawcami klas w dziedzinie wychowania;

3) pomoc i interwencję w klasach w nagłych wypadkach;

4) planowanie tematyki godzin wychowawczych;

5) rozeznanie potrzeb i zapewnienie pomocy materialnej uczniom, którzy tego potrzebują;

6) planowanie i organizowanie akcji profilaktycznych; 
7) organizację zajęć integracyjnych dla klas pierwszych;

8) opiekę indywidualną nad uczniami wymagającymi takiego wsparcia;

9) współpracę z placówkami specjalistycznymi (ośrodkami pomocy społecznej, poradniami psychologiczno-pedagogicznymi i rodzinnymi, placówkami terapeutycznymi);

10) stworzenie odpowiednich warunków oraz zaoferowanie czasu i własnego zainteresowania każdemu uczniowi i jego rodzicom, którzy potrzebują kontaktu z pedagogiem (Sałasiński, Badziukiewicz 2003, s. 22).

Ujęcie roli pedagoga w polskich szkołach znacznie zmieniły ministerialne przepisy dotyczące organizacji pomocy psychologiczno-pedagogicznej z 2010 (Rozporządzenie Ministra Edukacji Narodowej 2011), a następnie 2013 roku (Rozporządzenie Ministra Edukacji Narodowej 2013). Pierwsze z tych rozporządzeń zakładało model zespołowej pracy osób udzielających pomocy psychologiczno-pedagogicznej. Dla każdego ucznia potrzebującego takiej pomocy tworzono zespół składający się z nauczycieli, wychowawców oraz specjalistów prowadzących z nim zajęcia. Zespół ten planował i koordynował oraz realizował pomoc dla ucznia (Rozporządzenie Ministra Edukacji Narodowej 2011; \$19.1). W skład wszystkich zespołów z założenia wchodził pedagog szkolny, najczęściej także koordynował on ich pracę.

W przepisach z 2013 roku zasadę zespołowej pracy zachowano jedynie w odniesieniu do uczniów posiadających orzeczenie o potrzebie kształcenia specjalnego, dla których opracowuje się indywidualny program edukacyjno-terapeutyczny (Rozporządzenie Ministra Edukacji Narodowej 2013. \$21.2). Planowaniem i koordynowaniem pomocy psychologiczno-pedagogicznej udzielanej uczniom mają się obecnie zajmować wychowawcy klas (Rozporządzenie Ministra Edukacji Narodowej 2013. \$19.5). Można jednak mieć poważne wątpliwości, czy podołają tego typu obowiązkom. $Z$ całą pewnością oczekują pomocy i wsparcia ze strony pedagogów szkolnych.

Należy zaznaczyć, że od 2010 roku w ministerialnych rozporządzeniach dotyczących pomocy psychologiczno-pedagogicznej zadania pedagoga i psychologa są ujmowane łącznie. Ukazano je w tabeli 1. 
Tabela 1. Zadania pedagoga i psychologa szkolnego według rozporządzeń z 2010 i $2013 \mathrm{r}$.

\begin{tabular}{|c|c|}
\hline $\begin{array}{l}\text { Rozporządzenie Ministra Edukacji } \\
\text { Narodowej z } 17 \text { listopada } 2010 \text { r. }\end{array}$ & $\begin{array}{l}\text { Rozporządzenie Ministra Edukacji } \\
\text { Narodowej z } 30 \text { kwietnia } 2013 \text { r. }\end{array}$ \\
\hline $\begin{array}{l}\text { 1. Prowadzenie badań i działań diagno- } \\
\text { stycznych uczniów, w tym diagnozowa- } \\
\text { nie indywidualnych potrzeb rozwojowych } \\
\text { i edukacyjnych oraz możliwości psychofi- } \\
\text { zycznych uczniów w celu określenia przy- } \\
\text { czyn niepowodzeń edukacyjnych oraz } \\
\text { wspierania mocnych stron uczniów } \\
\text { 2. Minimalizowanie skutków zaburzeń roz- } \\
\text { wojowych, zapobieganie zaburzeniom za- } \\
\text { chowania oraz realizacja różnych form } \\
\text { pomocy w środowisku szkolnym i po- } \\
\text { zaszkolnym uczniów } \\
\text { 3. Prowadzenie terapii indywidualnej i gru- } \\
\text { powej }\end{array}$ & $\begin{array}{l}\text { 1. Prowadzenie badań i działań diagno- } \\
\text { stycznych uczniów, w tym diagnozowa- } \\
\text { nie indywidualnych potrzeb rozwojowych } \\
\text { i edukacyjnych oraz możliwości psychofi- } \\
\text { zycznych uczniów w celu określenia przy- } \\
\text { czyn niepowodzeń edukacyjnych oraz } \\
\text { wspierania mocnych stron uczniów } \\
\text { 2. Diagnozowanie sytuacji wychowawczych } \\
\text { w przedszkolu, szkole lub placówce w celu } \\
\text { rozwiązywania problemów wychowaw- } \\
\text { czych oraz wspierania rozwoju uczniów } \\
\text { 3. Udzielanie pomocy psychologiczno-pe- } \\
\text { dagogicznej w formach odpowiednich do } \\
\text { rozpoznanych potrzeb } \\
\text { 4. Podejmowanie działań z zakresu profilak- } \\
\text { tyki uzależnień i innych problemów dzie- } \\
\text { ci i młodzieży } \\
\text { 5. Minimalizowanie skutków zaburzeń roz- } \\
\text { wojowych, zapobieganie zaburzeniom za- } \\
\text { chowania oraz inicjowanie różnych form } \\
\text { pomocy w środowisku szkolnym i pozasz- } \\
\text { kolnym uczniów } \\
\text { 6. Inicjowanie i prowadzenie działań media- } \\
\text { cyjnych i interwencyjnych w sytuacjach } \\
\text { kryzysowych } \\
\text { 7. Pomoc rodzicom i nauczycielom w roz- } \\
\text { poznawaniu i rozwijaniu indywidual- } \\
\text { nych możliwości, predyspozycji i uzdol- } \\
\text { nień uczniów } \\
\text { 8. Wspieranie nauczycieli, wychowawców } \\
\text { grup wychowawczych i innych specjali- } \\
\text { stów w udzielaniu pomocy psychologicz- } \\
\text { no-pedagogicznej }\end{array}$ \\
\hline
\end{tabular}

Źródło: Rozporządzenie Ministra Edukacji Narodowej z dnia 17 listopada 2010 r. w sprawie zasad udzielania i organizacji pomocy psychologiczno-pedagogicznej w publicznych przedszkolach, szkołach i placówkach. Dz.U. 2011 Nr 228. Poz. 1487. \$29; Rozporządzenie Ministra Edukacji Narodowej z dnia 30 kwietnia 2013 r. w sprawie zasad udzielania i organizacji pomocy psychologiczno-pedagogicznej w publicznych przedszkolach, szkołach i placówkach. Dz.U. 2013 Nr 228. Poz. 532. \$23. 
Łączne ujmowanie zadań pedagoga i psychologa w szkole budzi spore wątpliwości. Między specyfiką roli zawodowej tych specjalistów istnieją jednak spore różnice. $Z$ całą pewnością role te nie są wzajemnie zastępowalne. Powstaje też wątpliwość, co w przypadku, gdy w szkole jest zatrudniony wyłącznie pedagog (a tak przecież jest najczęściej). Czy ma on wypełniać też zadania typowo psychologiczne? W tym kontekście należy pozytywnie ocenić fakt, iż z grupy zadań tych specjalistów wycofano prowadzenie terapii indywidualnej i grupowej (zadania znacznie „bardziej psychologiczne” niż pedagogiczne).

Pedagog i psycholog szkolny mają więc, w myśl najnowszych przepisów, być diagnostami, osobami udzielającymi pomocy psychologiczno-pedagogicznej, prowadzącymi działalność profilaktyczną, mediacyjną, wspierającymi innych pracowników szkoły w udzielaniu pomocy psychologiczno-pedagogicznej oraz pomagającymi rodzicom i nauczycielom w rozpoznawaniu i rozwijaniu potencjału uczniów. $\mathrm{Z}$ zakresu zadań pedagoga szkolnego usunięto udzielanie pomocy materialnej.

Powyższe ujęcie zadań pedagoga szkolnego wyraźnie koresponduje z koncepcją Bożeny Matyjas, która podkreśliła, iż pedagodzy szkolni przygotowują się do pełnienia różnych ról:

- doradcy metodycznego - niosącego pomoc nauczycielom-wychowawcom,

- opiekuna, terapeuty - bezpośrednio pomagającego uczniom,

- mediatora w interakcjach: uczeń-uczeń, uczeń-nauczyciel, uczeń-rodzic, rodzic-nauczyciel,

- konsultanta pomagającego rodzicom,

- inicjatora i koordynatora pracy opiekuńczo-wychowawczej,

- łącznika szkoły ze środowiskiem oraz instytucjami wspomagającymi szkołę w wypełnianiu przez nią różnorodnych zadań (Matyjas 2005, s. 85-86).

Prezentacja przemian koncepcji roli zawodowej pedagoga szkolnego jest dobrym punktem wyjścia do ukazania spojrzenia studentów pedagogiki na powyższe kwestie.

\section{OPINIE STUDENTEK PEDAGOGIKI NA TEMAT ROLI PEDAGOGA SZKOLNEGO}

Aby dowiedzieć się, jak rolę pedagoga w szkole postrzegają osoby przygotowujące się do pracy w tym zawodzie, przeprowadzono badania wśród studentów I i II roku pedagogiki studiów II stopnia specjalności pedagogika opiekuńczo-wychowawcza Uniwersytetu Rzeszowskiego. Badana grupa składała się z 73 studentek (44 z I roku i 29 z II roku) w wieku 21-25 lat (najwięcej z nich miało 22 lata - 41,10\%). 
Do badań wybrano osoby studiujące na studiach II stopnia, by zwiększyć prawdopodobieństwo, że wszyscy badani poznali w praktyce specyfikę zawodu pedagoga (z własnego doświadczenia albo w trakcie kształcenia na uczelni). Tak się też stało - wśród respondentek nie było osób, które w ogóle nie zetknęłyby się z pracą pedagoga szkolnego. Większość badanych uczęszczała do szkół, w których byli zatrudnieni pedagodzy (w przypadku szkoły podstawowej 46 osób - 63,01\%, w przypadku gimnazjum 54 osoby - 73,97\%, w przypadku szkoły ponadgimnazjalnej 68 osób - 93,15\%). Można zauważyć tendencję, że im wyższy poziom kształcenia, tym częściej w szkole obecny był pedagog. Wynika to w faktu, iż część respondentek uczęszczała do szkoły podstawowej w małych miejscowościach. Podczas praktyk pedagogicznych z pracą pedagoga szkolnego zapoznało się 61 badanych $(83,56 \%)$.

$\mathrm{W}$ przeprowadzonych badaniach posłużono się metodą sondażu diagnostycznego, techniką ankiety audytoryjnej. Starano się uzyskać odpowiedzi na następujące pytania:

1. Jak studenci pedagogiki postrzegają zadania pedagoga szkolnego?

2. Jakie trudności w realizacji przez pedagoga zadań dostrzegają badani?

3. Jaka jest opinia respondentów na temat modelu pedagoga szkolnego (jego pożądanych cech, wiedzy i umiejętności)?

4. Czy studenci pedagogiki chcą podjąć pracę w zawodzie pedagoga szkolnego i czy czują się do tego przygotowani?

\section{ZADANIA PEDAGOGA SZKOLNEGO W OPINII BADANYCH}

By dowiedzieć się, czym przede wszystkim - zdaniem respondentek - powinien się zajmować pedagog szkolny, posłużono się pytaniem półotwartym, przedstawiając im listę ogólnie sformułowanych zadań tego specjalisty z możliwością uzupełnienia jej o własne propozycje. Należało wybrać z niej trzy. Odpowiedzi respondentek ukazuje tabela 2.

Tabela 2. Opinie studentek pedagogiki na temat zadań pedagoga szkolnego

\begin{tabular}{|l|l|c|}
\hline \multicolumn{1}{|c|}{ Zadanie } & $\mathrm{N}$ & $\%$ \\
\hline Pomoc uczniom przeżywającym trudności w rodzinie & 39 & 53,42 \\
\hline Pomoc uczniom przeżywającym trudności w kontaktach z rówieśnikami & 38 & 52,05 \\
\hline Praca z uczniami sprawiającymi trudności wychowawcze & 38 & 52,05 \\
\hline Organizowanie zajęć profilaktycznych dla uczniów & 19 & 26,03 \\
\hline Pomoc uczniom mającym trudności w nauce & 18 & 24,66 \\
\hline Troska o realizację w szkole praw dziecka & 13 & 17,81 \\
\hline
\end{tabular}




\begin{tabular}{|l|r|r|}
\hline \multicolumn{1}{|c|}{ Zadanie } & $\mathrm{N}$ & $\%$ \\
\hline Prowadzenie zajęć integracyjnych dla uczniów & 12 & 16,43 \\
\hline Pomoc rodzicom mającym trudności z własnymi dziećmi & 12 & 16,43 \\
\hline Pomoc nauczycielom w działalności wychowawczej & 10 & 13,70 \\
\hline Psychoedukacja rodziców & 9 & 12,33 \\
\hline Psychoedukacja nauczycieli & 6 & 8,22 \\
\hline Prowadzenie godzin wychowawczych & 3 & 4,11 \\
\hline Brak wskazania jednego zadania & 2 & 2,74 \\
\hline
\end{tabular}

Uwaga: suma \% w tabeli jest większa od 100, gdyż badane wskazywały trzy odpowiedzi.

Jak wynika $\mathrm{z}$ danych zawartych w tabeli, pedagog szkolny powinien, według badanych studentek, zajmować się przede wszystkim pomocą uczniom - tym, którzy przeżywają trudności w rodzinie, w kontaktach z rówieśnikami oraz sprawiają trudności wychowawcze. Takie opinie respondentek odbiegają od tych wyrażonych przez objęte badaniami przez Teresę Lewandowską-Kidoń nauczycielki i studentki pedagogiki, dla których najważniejszymi zadaniami pedagoga były pomoc nauczycielom oraz rodzicom w pełnieniu przez nich funkcji wychowawczej, a także wspieranie psychicznie uczniów (Lewandowska-Kidoń 2015, s. 246).

Rola pedagoga przez badane studentki Uniwersytetu Rzeszowskiego kojarzona jest więc przede wszystkim z pomaganiem uczniom, którzy znaleźli się w trudnej sytuacji bądź sprawiają trudności wychowawcze. Na szóstym miejscu wśród najważniejszych - zdaniem respondentek - zadań tego specjalisty znalazła się troska o realizację w szkole praw dzieci. Zagadnienie to zostało pogłębione przez umieszczenie w kwestionariuszu ankiety konkretnego pytania, o realizację jakich praw uczniów pedagog powinien się szczególnie zatroszczyć. Wśród odpowiedzi badanych na pierwszym miejscu znalazły się dwa prawa: prawo do nauki, wiedzy oraz prawo do swobody wypowiedzi, myśli, wyrażania swoich opinii (oba wskazane przez 17 osób - 23,29\% ogółu respondentek). Kolejne miejsca zajęły: prawo do szacunku (16 osób - 21,92\%), prawo do bezpieczeństwa fizycznego i psychicznego oraz prawo do wszechstronnego rozwoju (po 9 osób - 12,33\%), prawo do równości (8 osób - 10,96\%), do odpoczynku (7 osób - 9,59\%), do indywidualności (6 osób - 8,22\%). Po 4 osoby (5,48\%) podawały prawo do sprawiedliwej oceny oraz prawo do rozwijania zainteresowań, po $3(4,11 \%)$ - prawo do wolności od przemocy, do sprawiedliwego traktowania przez nauczycieli, do podmiotowego traktowania, do akceptacji, po $2(2,74 \%)$ - prawo do kontaktów z rówieśnikami, do informacji oraz ogólnie - wszystkie prawa. Po 1 osobie wskazało następujące prawa: prawo do nauki w domu, do posiadania praw, do samorealizacji, do równego dostępu do dodatkowych zajęć, do uznania, do otrzymania pomocy, do wycho- 
wywania w rodzinie wolnej od trosk, do pomocy psychologicznej, do znajomości praw, do zaspokojenia potrzeb, a także ogólnie prawa osobiste, społeczne i socjalne.

Należy stwierdzić, iż pedagog szkolny kojarzy się badanym studentkom z rzecznikiem praw uczniów, który dba nie tylko o to, by ich prawo do zdobywania wiedzy było realizowane, ale także o to, by przebiegało to z zachowaniem ich prawa do wyrażania swoich poglądów w atmosferze szacunku i bezpieczeństwa.

Kontynuując problem zadań pedagoga szkolnego, poproszono badane studentki o ocenę realności realizacji poszczególnych zadań przypisywanych pedagogowi w ministerialnych przepisach. Okazało się, że zadania pedagoga szkolnego określone w ministerialnych przepisach jako bardziej możliwe do realizacji oceniły studentki II roku $-5 \mathrm{z}$ tych zadań przez ponad połowę respondentek $\mathrm{z}$ tej grupy było określanych jako w pełni realne. Respondentki z I roku większość zadań oceniały przeważnie jako średnio realne. Częściej także niż starsze koleżanki zadania pedagoga określały jako mało realne.

Aby precyzyjniej ukazać ocenę realności realizacji poszczególnych zadań pedagoga szkolnego dokonaną przez badane, poszczególnym punktom skali ocen przyporządkowano punkty: za ocenę „w pełni realne” - 3 punkty, za „średnio realne” - 2 punkty, za „mało realne” - 1 punkt. Następnie wyliczono średnią liczbę punktów, jaką badane przyporządkowały danemu zadaniu. Wyniki ukazuje tabela 3.

Tabela 3. Możliwość realizacji przez pedagoga szkolnego przypisanych mu w 2013 r. zadań w ocenie badanych

\begin{tabular}{|c|c|c|c|c|c|c|}
\hline \multirow[b]{2}{*}{ Zadanie } & \multicolumn{2}{|c|}{ II rok } & \multicolumn{2}{|c|}{ I rok } & \multicolumn{2}{|c|}{ Ogółem } \\
\hline & $\begin{array}{c}\text { Średnia } \\
\text { liczba } \\
\text { punktów }\end{array}$ & $\begin{array}{c}\text { Miejsce } \\
\text { w hierarchii }\end{array}$ & $\begin{array}{c}\text { Średnia } \\
\text { liczba } \\
\text { punktów }\end{array}$ & $\begin{array}{c}\text { Miejsce } \\
\text { w hierarchii }\end{array}$ & $\begin{array}{c}\text { Średnia } \\
\text { liczba } \\
\text { punktów }\end{array}$ & $\begin{array}{c}\text { Miejsce } \\
\text { w hierarchii }\end{array}$ \\
\hline 1 & 2,48 & V & 2,07 & VII & 2,23 & VI \\
\hline 2 & 2,63 & II & 2,20 & IV & 2,37 & III \\
\hline 3 & 2,63 & II & 2,41 & II & 2,49 & II \\
\hline 4 & 2,67 & I & 2,45 & I & 2,54 & I \\
\hline 5 & 2,33 & VI & 2,18 & $\mathrm{~V}$ & 2,20 & VII \\
\hline 6 & 2,33 & VI & 1,91 & VIII & 2,07 & VIII \\
\hline 7 & 2,52 & IV & 2,16 & VI & 2,30 & $\bar{V}$ \\
\hline 8 & 2,56 & III & 2,23 & III & 2,35 & IV \\
\hline
\end{tabular}

Uwaga: zadania pedagoga według rozporządzenia z 2013 r. ukazano w tabeli 1.

Wszystkie respondentki oceniały poszczególne zadania pedagoga szkolnego jako co najmniej średnio realne. Za najbardziej możliwe do zrealizowania uznano 
podejmowanie działań z zakresu profilaktyki uzależnień i innych problemów dzieci i młodzieży, udzielanie pomocy psychologiczno-pedagogicznej w formach odpowiednich do rozpoznanych potrzeb, a także diagnozowanie sytuacji wychowawczych w przedszkolu, szkole lub placówce w celu rozwiązywania problemów wychowawczych oraz wspierania rozwoju uczniów. Są to zadania, które pedagodzy szkolni podejmują najczęściej, dotyczą one szerokiego grona uczniów, wielce prawdopodobne jest więc, że respondentki właśnie z realizacją tych zadań zetknęły się w trakcie realizacji praktyk czy wcześniej jako uczennice w szkołach.

$\mathrm{Na}$ ostatnim miejscu, jeśli chodzi o ocenę realności zadania - zarówno wśród ogółu badanych studentek, jak i w obu grupach wyodrębnionych ze względu na rok studiów - znalazło się inicjowanie i prowadzenie działań mediacyjnych i interwencyjnych w sytuacjach kryzysowych. Jest to nowe zadanie, stosunkowo niedawno przypisane pedagogowi. Badane studentki mogły więc przypuszczać, iż pedagodzy szkolni niekoniecznie są do jego realizacji przygotowani. Ponadto one same w trakcie kształcenia na uczelni poznają specyfikę prowadzenia działań interwencyjnych i mediacyjnych, są świadome trudności z nimi związanych, co mogło wpłynąć na ich ocenę.

Hierarchie zadań stworzone ze względu na ocenę stopnia możliwości ich realizacji w przypadku obu grup badanych (z I i II roku) są bardzo podobne. Studentki z I roku jednak niżej oceniają stopień realności realizacji wszystkich zadań pedagoga. Różnice te mogą być spowodowane faktem, iż osoby z II roku niebawem kończą studia, będą rozpoczynać pracę, ocena zadań pedagoga szkolnego jako nierealnych już „na starcie” byłaby więc czymś dziwnym.

Generalnie można stwierdzić, iż badane z pewną dozą krytycyzmu odniosły się do zadań przypisywanych pedagogowi szkolnemu. Interesująca wydaje się więc kwestia, jakie bariery, ich zdaniem, nie pozwalają pedagogom w pełni realizować swoich obowiązków. Temu zagadnieniu będą poświęcone dalsze rozważania.

\section{BARIERY I TRUDNOŚCI W PRACY PEDAGOGA W PERCEPCJI RESPONDENTEK}

Utrudnień w pracy pedagoga dotyczyły dwa pytania zawarte w kwestionariuszu ankiety. Pierwsze $\mathrm{z}$ nich miało charakter półotwarty. Respondentkom podano listę potencjalnych barier w pracy pedagoga (z możliwością uzupełnienia jej, z której jednak żadna $\mathrm{z}$ nich nie skorzystała). Ich zadaniem było wskazanie trzech według nich najważniejszych. Ich odpowiedzi ukazuje tabela 4 . 
Tabela 4. Opinie studentek pedagogiki na temat barier w pracy pedagoga szkolnego

\begin{tabular}{|l|c|c|}
\hline \multicolumn{1}{|c|}{ Bariera } & $\mathrm{N}$ & $\%$ \\
\hline $\begin{array}{l}\text { Niewłaściwe rozumienie roli pedagoga przez nauczycieli, wyręczanie się } \\
\text { przez nich pedagogiem w pracy wychowawczej }\end{array}$ & 47 & 64,38 \\
\hline Za mało etatów pedagogów w szkołach & 34 & 46,58 \\
\hline Nadmiar dokumentacji & 33 & 45,21 \\
\hline Niezrozumienie roli pedagoga przez rodziców & 23 & 31,51 \\
\hline Wyręczanie się przez dyrekcję pedagogiem w działalności wychowawczej & 23 & 31,51 \\
\hline Brak innych specjalistów w szkole & 20 & 27,40 \\
\hline Niedostateczne przygotowanie do pracy pedagoga w trakcie studiów & 17 & 23,29 \\
\hline Ryzyko wypalenia zawodowego & 14 & 19,18 \\
\hline Za dużo obowiązków & 7 & 9,59 \\
\hline Brak zaznaczenia 1 odpowiedzi & 1 & 1,37 \\
\hline
\end{tabular}

Uwaga: suma \% w tabeli jest większa niż 100, gdyż badane wskazywały 3 odpowiedzi.

Za największą barierę utrudniającą pedagogowi realizację jego zadań badane uznały niewłaściwe rozumienie przez nauczycieli roli pedagoga. Nie jest to odpowiedź zaskakująca - oczekiwanie przez nauczycieli od pedagoga szkolnego rozwiązywania wszystkich trudnych sytuacji jest zjawiskiem dość częstym, prawdopodobnie więc badane miały okazję zaobserwować tego typu sytuacje $\mathrm{w}$ trakcie praktyk albo usłyszeć o nich od samych pedagogów. Respondentki słusznie zwróciły także uwagę na fakt, że specjalistów w polskich szkołach jest po prostu za mało, a także na to, iż są oni nadmiernie obciążani prowadzeniem dokumentacji (nadmiar dokumentacji był najważniejszą barierą dla studentek I roku).

Respondentki poproszono również o samodzielne określenie (pytanie otwarte) największych trudności w pracy pedagoga szkolnego. Ich opinie dotyczące tego zagadnienia ukazuje tabela 5 .

Tabela 5. Największe trudności w pracy pedagoga szkolnego w opiniach studentek pedagogiki

\begin{tabular}{|l|r|c|}
\hline \multicolumn{1}{|c|}{ Trudność } & N & $\%$ \\
\hline Brak współpracy z rodzicami & 11 & 15,07 \\
\hline Dużo dokumentacji & 11 & 15,07 \\
\hline Stereotyp pedagoga, jego zły obraz - pedagog jako „straszak” & 11 & 15,07 \\
\hline Brak współpracy ze strony uczniów & 9 & 12,33 \\
\hline Opór, niechęć dzieci i młodzieży & 9 & 12,33 \\
\hline
\end{tabular}




\begin{tabular}{|c|c|c|}
\hline Trudność & $\mathrm{N}$ & $\%$ \\
\hline Brak współdziałania ze strony współpracowników & 8 & 10,96 \\
\hline Trudna młodzież, nawiązywanie z nią kontaktu & 6 & 8,22 \\
\hline $\begin{array}{l}\text { Tok postępowania w trudnych sytuacjach, trudne sytuacje, które trze- } \\
\text { ba rozwiązać }\end{array}$ & 5 & 6,85 \\
\hline Brak współpracy nauczycieli, rodziców i dzieci & 4 & 5,48 \\
\hline Dzieci z różnymi trudnościami & 3 & 4,11 \\
\hline Mało godzin pracy & 3 & 4,11 \\
\hline Nadmiar obowiązków & 3 & 4,11 \\
\hline Agresja uczniów & 2 & 2,74 \\
\hline Za dużo uczniów na jednego pedagoga & 2 & 2,74 \\
\hline Braki finansowe & 2 & 2,74 \\
\hline Zachowanie cierpliwości, spokoju & 2 & 2,74 \\
\hline $\begin{array}{l}\text { Inne - wskazywane } 1 \text { raz: milczenie ucznia; zaprzeczenia ze strony ucznia; } \\
\text { trudności w komunikacji; patologia; trudni rodzice; sprostanie narzuco- } \\
\text { nym wymaganiom; procedury szkolne; brak zrozumienia rodziców i na- } \\
\text { uczycieli; poznanie sytuacji rodzinnej ucznia; rozpoznanie trudności } \\
\text { ucznia; stres; łączenie problemów osobistych ze szkolnymi; niedocenianie } \\
\text { pedagoga; zdobycie autorytetu; duża odpowiedzialność; brak szacunku; } \\
\text { brak pomocy; nieszczerość; neutralność; konieczność posiadania odpor- } \\
\text { ności psychicznej; utożsamianie się z problemami innych; brak wsparcia } \\
\text { dyrekcji; prawidłowa diagnoza; brak praktycznego przygotowania; po- } \\
\text { moc rodzinom problemowym, np. z alkoholem; różnice temperamentu } \\
\text { między pedagogiem a wychowankiem; wypalenie zawodowe; zdobycie } \\
\text { zaufania; poprawne, satysfakcjonujące rozwiązanie sprawy; „dotarcie” do } \\
\text { ucznia; taka organizacja czasu, by móc go poświęcić każdemu uczniowi; } \\
\text { obciążenie psychiczne }\end{array}$ & 32 & 43,84 \\
\hline
\end{tabular}

Uwaga: suma \% w tabeli jest większa niż 100, gdyż badane miały możliwość wskazania kilku odpowiedzi.

Jak pokazano w tabeli, trudności w pracy pedagoga dostrzegane przez respondentki są bardzo różnorodne, właściwie nie ma jednoznacznie dominujących. Trudności wskazywane najczęściej wyraźnie korespondują z barierami, które sygnalizowały badane w odpowiedzi na omówione wyżej pytanie. Zauważa się, iż trudności w pracy pedagoga wynikają, zdaniem badanych, z braku współpracy wszystkich osób zaangażowanych w udzielanie pomocy uczniom, a także braku chęci współpracy u samych uczniów. Brak współpracy z rodzicami uczniów jako utrudnienie $\mathrm{w}$ pracy pedagoga wskazywały również osoby badane przez T. Lewandowską-Kidoń (Lewandowska-Kidoń 2015, s. 247).

Problem - zdaniem studentek pedagogiki biorących udział w opisywanych w tekście badaniach - stanowią też „trudne przypadki”, z którymi musi pracować 
pedagog, oraz kwestie proceduralne, organizacyjne i formalne. Dla pokonania identyfikowanych przez badane trudności i barier konieczne jest posiadanie przez pedagoga określonych cech osobowościowych oraz dysponowanie konkretną wiedzą i umiejętnościami. Są to elementy składowe pożądanego modelu pedagoga szkolnego.

\section{MODEL PEDAGOGA W OPINIACH BADANYCH STUDENTEK}

Istotnym zagadnieniem uwzględnionym $\mathrm{w}$ prowadzonych badaniach było postrzeganie przez studentki pedagogiki pożądanych cech pedagoga szkolnego. Ich odpowiedzi dotyczące tej kwestii ukazuje tabela 6 .

Tabela 6. Pożądane cechy pedagoga w percepcji badanych

\begin{tabular}{|l|c|c|}
\hline \multicolumn{1}{|c|}{ Określenie cechy pedagoga } & $\mathrm{N}$ & $\%$ \\
\hline Wyrozumiały & 31 & 42,47 \\
\hline Empatyczny & 27 & 36,99 \\
\hline Otwarty & 24 & 32,88 \\
\hline Cierpliwy & 22 & 30,14 \\
\hline Odpowiedzialny & 16 & 21,92 \\
\hline Pomocny, chętny do pomocy & 14 & 19,18 \\
\hline Kompetentny & 12 & 16,43 \\
\hline Wrażliwy & 11 & 15,07 \\
\hline Godny zaufania & 9 & 12,33 \\
\hline Sumienny & 8 & 10,96 \\
\hline Troskliwy & 7 & 9,59 \\
\hline Tolerancyjny & 7 & 9,59 \\
\hline Konsekwentny, wytrwały & 6 & 8,22 \\
\hline Sprawiedliwy & 5 & 6,85 \\
\hline Obiektywny & 5 & 6,85 \\
\hline Życzliwy & 4 & 5,48 \\
\hline Pomysłowy, kreatywny & 4 & 5,48 \\
\hline Przyjazny & 4 & 5,48 \\
\hline Sympatyczny, miły & 4 & 5,48 \\
\hline Kulturalny, uprzejmy & 4 & 5,48 \\
\hline Rzetelny & 3 & 4,11 \\
\hline Stanowczy & 3 & 4,11 \\
\hline Szczery & 3 & 4,11 \\
\hline
\end{tabular}




\begin{tabular}{|l|c|c|}
\hline \multicolumn{1}{|c|}{ Określenie cechy pedagoga } & $\mathrm{N}$ & $\%$ \\
\hline Zaradny & 3 & 4,11 \\
\hline Uczciwy & 3 & 4,11 \\
\hline Spokojny & 3 & 4,11 \\
\hline Spostrzegawczy & 2 & 2,74 \\
\hline Obowiązkowy & 2 & 2,74 \\
\hline Lojalny & 2 & 2,74 \\
\hline Dyskretny & 2 & 2,74 \\
\hline Łatwo nawiązujący kontakty & 2 & 2,74 \\
\hline Nieoceniający & 2 & 2,74 \\
\hline Asertywny & 2 & 2,74 \\
\hline Odważny & 2 & 2,74 \\
\hline Szczery & 2 & 2,74 \\
\hline Autentyczny & 2 & 2,74 \\
\hline Akceptujący wychowanków & 2 & 2,74 \\
\hline Pracowity & 2 & 2,74 \\
\hline Zaangażowany & 2 & 2,74 \\
\hline Bezinteresowny & 2 & 2,74 \\
\hline $\begin{array}{l}\text { Inne - wskazywane 1 raz: nie wzbudza strachu; pogodny; kochający dzie- } \\
\text { ci; współpracuje z gronem pedagogicznym, rodzicami; ambitny; umie- } \\
\text { jący aktywnie słuchać; podmiotowo traktujący dzieci; opanowany; do- } \\
\text { strzegający problemy ucznia; dobry mediator; bez uprzedzeń; szanują- } \\
\text { cy innych; prawdomówny; autorytet; ,zarażający” do działania; będący } \\
\text { dobrym przykładem; altruista; z dużym doświadczeniem; inteligentny }\end{array}$ & 19 & 26,03 \\
\hline
\end{tabular}

Uwaga: suma \% w tabeli jest większa niż 100, gdyż badane miały możliwość wskazania kilku odpowiedzi.

Jak wynika $\mathrm{z}$ danych zawartych $\mathrm{w}$ tabeli, badanym żadna $\mathrm{z}$ cech dobrego pedagoga nie wydawała się na tyle oczywista, by wymieniła ją co najmniej połowa z nich. Najważniejsze dla respondentek były: wyrozumiałość, empatia, otwartość i cierpliwość. Generalnie można zauważyć, iż wymieniano głównie cechy istotne $\mathrm{w}$ relacji $\mathrm{z}$ drugim człowiekiem (przede wszystkim uczniem), a nie te związane z profesjonalną realizacją zawodowych obowiązków.

Badane poproszono również o określenie wiedzy niezbędnej pedagogowi szkolnemu. Na pytanie dotyczące tej kwestii respondentki najczęściej odpowiadały w sposób ogólny, iż pedagogowi szkolnemu jest potrzebna wiedza pedagogiczna (34 osoby - 46,58\%) i psychologiczna ( 28 osób - 38,36\%), a także „wiedza praktyczna” - wynikająca z doświadczenia pedagogicznego (13 osób - 17,81\%), wiedza dotycząca organizacji pracy pedagoga, pracy z dziećmi i rodzinami, udzielania pomocy 
(10 osób - 13,70\%), ogólnie - wiedza teoretyczna oraz konkretna wiedza o uczniach i ich rodzinach (po 9 osób - 12,33\%). Jako niezbędną pedagogowi wskazywano również wiedzę socjologiczną i z zakresu psychologii rozwojowej (po 8 osób - 10,96\%), wiedzę dotyczącą metod wychowania i profilaktyki oraz prawną dotyczącą najnowszych przepisów (po 7 osób - 9,59\%), wiedzę z zakresu profilaktyki (5 osób -6,85\%), dotyczącą organizacji zajęć, tworzenia strategii oraz ogólnie wiedzę prawną (po 4 osoby - 5,48\%). Wspominano również o wiedzy dotyczącej współpracy z rodzicami oraz znajomości praw dziecka (po 2 osoby - 2,74\%), jak również: wiedzy z zakresu biomedycznych podstaw rozwoju, biologii, filozofii, pracy socjalnej, metodologii badań pedagogicznych, dotyczącej poradnictwa, wiedzy na temat problemów młodzieży, uzależnień oraz organizacji pomocowych (po 1 osobie).

Oprócz wiedzy pedagog szkolny musi posiadać również konkretne umiejętności. Badane studentki zapytano, jakie umiejętności są w tym zawodzie najważniejsze. Podobnie jak w przypadku wiedzy, tu także nie pojawiła się powszechnie wymieniana odpowiedź. Najczęściej wskazywano umiejętności w zakresie komunikacji interpersonalnej (tak odpowiedziały 23 osoby - 31,51\%), umiejętność nawiązywania kontaktów (15 osób - 20,55\%), umiejętność rozwiązywania problemów (10 osób - 13,70\%), rozwiązywania konfliktów (9 osób - 12,33\%), aktywnego słuchania (7 osób - 9,59\%). Po 4 osoby $(5,48 \%)$ wspominały o umiejętności słuchania i umiejętności współpracy, po $3(4,11 \%)$ - umiejętności asertywnego zachowania i dobrej organizacji pracy, po $2(2,74 \%)$ - umiejętności wzbudzania zaufania, okazywania empatii, radzenia sobie ze stresem, podmiotowego traktowania wychowanków oraz ogólnie - umiejętnościach wychowawczych. Pojawiały się również pojedyncze odpowiedzi wskazujące jako najważniejsze w pracy pedagoga następujące umiejętności: umiejętność tworzenia planów odpowiednich do sytuacji, sporządzania dokumentacji, pracy z uczniem, pracy z rodzicami, dostrzegania w każdym dziecku dobra, poświęcania każdemu dziecku czasu indywidualnie, podejmowania szybkich decyzji, okazywania współczucia, kontrolowania emocji, radzenia sobie w sytuacjach trudnych, pełnej akceptacji wychowanka, obserwacji, prowadzenia profilaktyki, zrozumienia innych, zachowania elastyczności w działaniu, trafnej diagnozy, udzielania dobrych rad, odpowiedniego podejścia do ucznia, dotarcia do każdego ucznia.

Jak widać, katalog umiejętności niezbędnych w pracy pedagoga, stworzony przez badane studentki pedagogiki, jest obszerny. Czołowe miejsca zajmują w nim umiejętności interpersonalne, istotne $\mathrm{w}$ relacji pedagoga $\mathrm{z}$ uczniami. Takie spojrzenie na kwestię pożądanych umiejętności pedagoga szkolnego dowodzi zrozumienia przez badane specyfiki jego roli zawodowej. 


\section{CHĘĆ PODJĘCIA PRZEZ BADANE STUDENTKI PEDAGOGIKI PRACY W ZAWODZIE PEDAGOGA SZKOLNEGO}

Analiza przytoczonych wyżej odpowiedzi badanych na pytania zawarte w kwestionariuszu ankiety skłania do wniosku, iż doskonale zdają sobie one sprawę z wymagań związanych z zawodem pedagoga szkolnego, wyzwań pojawiających się w jego pracy. Dlatego interesująca wydaje się kwestia chęci podjęcia się przez nie pełnienia tej roli zawodowej. Wśród respondentek 18 osób $(24,66 \%)$ zdecydowanie nie chce pracować w zawodzie pedagoga szkolnego. Jako uzasadnienie podawały one: chęć wykonywania innego zawodu (4 osoby - 5,48\%), inne zainteresowania $(2-2,74 \%)$ oraz: przekonanie, że to trudny zawód, pedagog ma mało kontaktów z uczniami, naprawdę niewiele może pomóc, wskazywały na złą opinię o pedagogu, preferowanie pracy ze starszymi ludźmi, osobami niepełnosprawnymi, młodszymi dziećmi, pracy nauczyciela, pracy w placówce opiekuńczej, brak powołania (po 1 osobie).

$\mathrm{Z}$ pozostałych badanych 3 wprawdzie preferują inną pracę, ale nie wykluczają podjęcia pełnienia funkcji pedagoga szkolnego. Sporo respondentek chce pracować w zawodzie pedagoga - najwięcej w szkole podstawowej (39 osób - 53,43\%), znacznie mniej w gimnazjum i szkole ponadgimnazjalnej (po 7 osób - 9,59\%). Kilka osób wskazywało dwa preferowane typy szkół, a 4 osoby stwierdziły, iż chciałyby pracować jako pedagog i nie ma dla nich znaczenia, w jakiej szkole.

W tym miejscu warto przytoczyć dane na temat oceny respondentek dotyczącej własnego przygotowania do pełnienia roli pedagoga szkolnego. Z ogółu badanych $46,58 \%$ (34 osoby) czuje się przygotowanymi do roli pedagoga, $42,47 \%$ (31 osób) - wręcz przeciwnie, 6 respondentek określiło się jako jeszcze nie w pełni przygotowane do tego zawodu, a 2 nie udzieliły odpowiedzi.

Czego brakuje respondentkom, by optymalnie wypełniać tę rolę? Badane wskazywały głównie: brak odpowiedniej liczby praktyk ( 23 osoby - 31,51\%), brak praktycznych zajęć na uczelni, brak wiedzy i doświadczenia (po 3 osoby -4,11\%). Odpowiedzi te nie zaskakują - kształcenie uniwersyteckie, w którym nacisk kładzie się na wiedzę, a nie kształtowanie umiejętności i praktyczne zajęcia, zapewne nie przygotowuje optymalnie do realizacji zadań pedagoga.

\section{PODSUMOWANIE}

$\mathrm{Z}$ odpowiedzi badanych na pytania zawarte $\mathrm{w}$ kwestionariuszu ankiety wyłania się następujący model pedagoga szkolnego:

1) pedagog - według respondentek - jest pracownikiem szkoły, którego rola sprowadza się przede wszystkim do pomagania uczniom 
doświadczającym różnego typu trudności - w rodzinie, kontaktach z rówieśnikami - oraz tym, którzy sprawiają trudności wychowawcze;

2) ważne jest również, by był on rzecznikiem praw ucznia, dbającym o realizację jego prawa do wypowiadania własnego zdania, prawa do nauki oraz do szacunku;

3) powinien on charakteryzować się cechami ułatwiającymi nawiązywanie kontaktu i pracę z dziećmi i młodzieżą - być wyrozumiałym, empatycznym, otwartym i cierpliwym, a także odpowiedzialnym, chętnym do pomocy, a przy tym kompetentnym. Istotne są: posiadanie przez pedagoga wiedzy pedagogicznej i psychologicznej oraz doświadczenia pedagogicznego, jak również znajomość uczniów i ich rodzin. Pedagog powinien mieć rozwinięte umiejętności interpersonalne - przede wszystkim komunikacyjne, nawiązywania kontaktów, a także rozwiązywania problemów i konfliktów.

Zadania przypisane pedagogowi szkolnemu w ministerialnych przepisach są, według respondentek, co najmniej średnio możliwe do realizacji. Nie oznacza to jednak, że w pracy tego specjalisty nie pojawiają się bariery. Poważnym utrudnieniem dla pedagoga jest stereotyp dotyczący jego roli zawodowej, który sprawia, że specjalista ten bywa traktowany jako „straszak na niegrzeczne dzieci”, wysyłane do niego za karę. Problemy stwarza także konieczność prowadzenia rozbudowanej dokumentacji, jak również brak chęci współpracy ze strony rodziców, nauczycieli i uczniów.

Badane studentki trafnie postrzegają istotę pracy pedagoga szkolnego, który powinien być $\mathrm{w}$ szkole rzecznikiem praw i interesów uczniów. Zdają sobie sprawę, że nie jest to praca łatwa, bezproblemowa. Mimo to większość z nich chciałaby pracować w tym zawodzie, choć niekoniecznie czuje się do tego przygotowana.

\section{LITERATURA}

Badora S., Czeredrecka B., Marzec D. (2001). Rodzina i formy jej wspomagania. Kraków.

Charakterystyka zawodu, [online], www.pedagogszkolny.pl (dostęp: 18.10.2015). Jundziłł I. (1980). Rola zawodowa pedagoga szkolnego. Warszawa. Jundziłł I. (1993). Pedagog szkolny. W: W. Pomykało (red.). Encyklopedia pedagogiczna. Warszawa, s. 533-535.

Lewandowska-Kidoń T. (2015). Rola pedagoga we współczesnej szkole w opinii nauczycieli i studentów pedagogiki. W: T. Zubrzycka-Maciąg, M. Korczyński, M. Okrasa (red.). W trosce o wychowanie. Lublin, s. 239-240. 
Matyjas B. (2005). Pedagog szkolny. W: U. Śmietana (red.). Encyklopedia pedagogiczna XXI wieku. T. 4. Warszawa 2005, s. 85-87.

Rozporządzenie Ministra Edukacji Narodowej i Sportu z dnia 7 stycznia 2003 r. w sprawie zasad udzielania i organizacji pomocy psychologiczno-pedagogicznej w publicznych przedszkolach, szkołach i placówkach. Dz.U. 2003 Nr 11. Poz. 114.

Rozporządzenie Ministra Edukacji Narodowej z dnia 15 stycznia 2001 r. w sprawie zasad udzielania i organizacji pomocy psychologiczno-pedagogicznej w publicznych przedszkolach, szkołach i placówkach. Dz.U. 2001. Nr 13. Poz. 110.

Rozporządzenie Ministra Edukacji Narodowej z dnia 17 listopada 2010 r. w sprawie zasad udzielania i organizacji pomocy psychologiczno-pedagogicznej w publicznych przedszkolach, szkołach i placówkach. Dz.U. 2011. Nr 228. Poz. 1487.

Rozporządzenie Ministra Edukacji Narodowej z dnia 30 kwietnia 2013 r. w sprawie zasad udzielania i organizacji pomocy psychologiczno-pedagogicznej w publicznych przedszkolach, szkołach i placówkach. Dz.U. 2013. Nr 228. Poz. 532. Sałasiński M., Badziukiewicz B. (2003). Vademecum pedagoga szkolnego. Warszawa. Załącznik do Zarządzenia Ministra Oświaty i Wychowania z dnia 7 listopada 1975 r. w sprawie pracy nauczyciela - pedagoga szkolnego. Dz.Urz. MOiW 1975 r. Nr 11. Poz. 112.

\section{THE ROLE OF THE PEDAGOGUE IN THE OPINION OF STUDENTS OF EDUCATION}

Abstract: School counselor (pedagogue) is a specialist most often employed in Polish schools. The profession was established in the school year 1973/1974, and for many years the authorities tried to clarify the list of tasks performed by its representatives.

In the essay, the process of shaping the specifics of the role of professional school counselors has been taken into consideration The author analyzed the results of research on this issue, carried out among students of pedagogy. She discussed respondents' opinions about the school counselor's tasks, difficulties and barriers to their implementation, the standard of this specialist (his desired personality traits, knowledge and skills) as well as the students' willingness and readiness to work in this profession.

Keywords: school counselor (pedagogue), school, psychological and pedagogical assistance 